\title{
Juridical and Sociological Considerations of Judges in Granting Marriage Dispensation after Enactment Law No. 16 Of 2019
}

\author{
Maimunah \\ Institut Agama Islam Negeri Palangka Rava, Kalimantan Tengah, Indonesia, \\ Menteng, Kec. Jekan Rava, Kota Palangka Rava, Kalimantan Tengah 73112 \\ E-mail: maimunah@iain-palangkaraya.ac.id
}

\begin{abstract}
Abdul Helim
Institut Agama Islam Negeri Palangka Rava, Kalimantan Tengah, Indonesia, Menteng, Kec. Jekan Rava, Kota Palangka Rava, Kalimantan Tengah 73112 E-mail: helim1377@gmail.com

Noor Aina

Institut Agama Islam Negeri Palangka Rava, Kalimantan Tengah, Indonesia, Menteng, Kec. Jekan Rava, Kota Palangka Rava, Kalimantan Tengah 73112 E-mail: nooraina854@gmail.com

\section{Rabiatul Adawivah}

Institut Agama Islam Negeri Palangka Rava, Kalimantan Tengah, Indonesia, Menteng, Kec. Jekan Rava, Kota Palangka Rava, Kalimantan Tengah 73112 E-mail: rabiawendi@gmail.com
\end{abstract}

\begin{abstract}
This research is motivated by many applications for dispensation for Marriage after implementing the latest law related to the age limit for Marriage. This study examines judges' considerations from both normative and social aspects so that this dispensation application can be accepted. This research focuses on 1) how does the Judge review the application for a marriage dispensation after enacting Law Number 16 of 2019 at the Palangkaraya Religious Court? Religion of Palangkaraya?. This empirical research uses a statute approach and Islamic law. The research subjects are 5 (five) judges and 2 (two) informants who are substitute clerks at the Palangkaraya Religious Court. Data were collected through observation, interviews, documentation and analyzed through Islamic Laws and normative. The results of this study indicate that judges in deciding cases of marital dispensation do not only look at the Completeness of the legal administration. But also from a sociological perspective, granting a dispensation application sees aspects of the benefits that must be obtained to avoid more significant damage. The implication is that changes of the law related to marriage dispensation are increasing because it becomes a procedure to complete the marriage administration for underage couples in the provisions of the law.
\end{abstract}

Keywords: consideration; dispensation; marriage.

Juridical and Sociological Considerations of Judges in Granting Marriage Dispensation after Enactment Law No. 16 of 2019 


\section{INTRODUCTION}

Marriage is a provision of Allah SWT that is common and applies to all His creatures, whether in humans, animals, or plants. It is a method chosen by Him as a way for humans as His creatures to reproduce and preserve their life (Slamet \& Aminudin, 1999). Allah Almighty said in The Holy Quran:

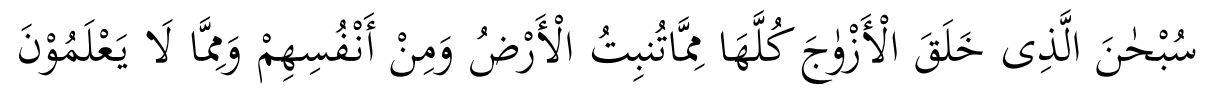

Meaning: "Then it is holy Allah who has created all pairs, both from what the earth has grown and from themselves and from what they do not know (Yaseen [36]: 36).

It is stated in the Islamic Law Compilation that Marriage is a strong agreement or can be called mïsàqan galiz a to obey Allah's orders and carry out it is worship. It is an initial process for building a household. As stated in Article 1 of Law no. 1 of 1974 concerning Marriage which reads:

Marriage is a physical and mental bond between a man and a woman as husband and wife to form a happy and eternal family or household based on the One Godhead.

The purpose of Marriage is to achieve happiness which includes life guidance full of love so that humans can live peacefully in families and communities. (Supiana, 2003) It is necessary to think maturity, mental readiness, and openness to each other in all things. They are the way to achieve happiness in Marriage. Marriage can be said to be happy if the goals are achieved or realized. Then, to achieve the noble goal of Marriage, of course, the prospective bride must have a cooked body and soul before Marriage.

One measure of maturity is age. In carrying out Marriage, age is essential because Marriage requires psychological maturity. The age of Marriage that is too young can lead to an increase in divorce cases due to a lack of awareness of Marriage's responsibility. It is because of a successful marriage with a readiness to take responsibility (Adhim, 2006).

Article 7 (1) of Law of the Republic of Indonesia Number 16 of 2019 concerning marriage "Marriage is only permitted if the man and woman have reached the age of 19 (nineteen) years". In the explanation, the purpose of determining the age limit is to maintain the health of husband and wife and offspring. The prohibition of marrying young also is listed in the Islamic Law Compilation article 15 paragraph (1). It is compatible with the emphasis of the principles of the Marriage Law. The prospective husband and wife must have their soul and body mature. Therefore they can realize the goal of Marriage well without ending in divorce and having kind and healthy offspring (Ali, 2007).

Juridical and Sociological Considerations of Judges in Granting Marriage Dispensation after Enactment Law No. 16 of 


\section{Jurnal Ilmiah Al-Syir'ah Vol. 19, No. 2 (2021): 136-148 \\ Website: http://journal.iain-manado.ac.id/index.php/JIS ISSN 2528-0368 (online) ISSN 1693-4202 (print)}

However, Law Number 16 the Year 2019 Article 7 (2) still provides space for dispensation for underage people for very urgent reasons accompanied by sufficient supporting evidence.

Marriage dispensation is a measure of leniency provided by the Court to prospective husband and wife who have not reached the age limit so that they can carry out a marriage. Applications for marriage dispensation are voluntary, namely cases that are petition in nature and in which there is no dispute so that there is no opponent whose product is in the form of a ruling (Arto, 2017).

Marriage dispensation is closely related to early Marriage. In Central Kalimantan, especially in the city of Palangkaraya, it is based on data from $B K K B N$ or mentioned as the National Population and Family Planning Board, until now the rate of early Marriage in Central Kalimantan is still high. This table is shown by the increase in applications for marriage dispensation, which has increased sharply from 2019 and 2020. Table 1 briefly shows the data of marriage dispensation cases in 2019-2020.

Table 1. Marriage Dispensation Case at the Palangkaraya Religious Court

\begin{tabular}{cc}
\hline Years & Amount \\
\hline 2019 & 20 \\
2020 & 66 \\
\hline
\end{tabular}

Source: SIPP PA Palangkaraya (http://pa-palangkaraya.go.id/)

In this case, the problem that the writer found in preliminary observations was that the Religious Courts in Palangkaraya City in 2019 - 2020 had received and determined 86 applications for marriage dispensation, and all of these requests were granted. For some reason, the Judge may reject the request for dispensation of Marriage if no element or 'illat can cause the person applying for the dispensation of Marriage to be married as soon as possible.

According to the author, this is a serious problem considering the cause of divorce, one of which is early Marriage. Therefore, the Court's discretion and prudence play a vital role in determining the application for marriage dispensation; whether it is granted or rejected, it must be by solid reasons to reduce the number of applications for marriage dispensation.

\section{RESEARCH METHODS}

This type of research used by the author is the empirical legal research method, or it is called juridical sociological research or also known as field research. This research uses a sociological juridical research type because it examines a problem that exists in society related to laws and regulations. For this reason, the researcher tries to describe the reality in the field according to what is being studied (Ali, 2015).

Juridical and Sociological Considerations of Judges in Granting Marriage Dispensation after Enactment Law No. 16 of 


\section{Jurnal Ilmiah Al-Syir'ah Vol. 19, No. 2 (2021): 136-148 \\ Website: http://journal.iain-manado.ac.id/index.php/JIS ISSN 2528-0368 (online) ISSN 1693-4202 (print)}

The approach used in this research is the statute approach and Islamic law by examining the legal rules that are the focus and are the central theme of a study. To solve the research problems, the researcher uses the statute approach and Islamic law to determine (Utsman, 2014).

The legal article 7 of Law Number 16 of 2019 concerns the age limit of Marriage. People may get married if they have reached the age of 19 for men and women. There are still many people who are married under the age of 19 . Then they have to apply for a marriage dispensation (Utsman, 2008).

The object of this research is the Judicial and Sociological Considerations of Judges in Providing Marriage Dispensation after the Enactment of Law Number 16 of 2019 at the Palangkaraya Religious Court.

The subjects of this study were judges at the Palangkaraya Religious Court, totaling 2 (two) subjects with the following criteria:

1. The Judge who handles applications for marriage dispensation.

2. The Judge has served at the Palangkaraya Religious Court for more than one year.

As for those who became supporting informants in this study, there were 2 (two) registrars worked at the Palangkaraya Religious Court. The researcher collected data in this study using observation and in-depth interviews using interview guidelines that developed according to field conditions and documentation.

Data analysis techniques are the methods used to analyze research data. After the data has been completely collected from both the field and documentation, the next stage is the analysis stage. The problem of this research is how the Judge assesses the application for marriage dispensation after the enactment of Law Number 16 of 2019 at the Religious Court of Palangkaraya City and the reasons for the Judge granting or rejecting the application for marriage dispensation after Law Number 16 of 2019. It analyzed with the theory of the Judge's authority, considerations judges, the theory of judge creativity, and maqashid sharia. From the Judge's Authority theory, the things analyzed are whether or not there is a rejection of a marriage dispensation application. The number of cases of a marriage dispensation application, the time limit for the decision on a marriage dispensation application, the scope of examination in Court, and the Judge's concerns about the phenomenon of marriage dispensation applications.

From the Judge's theory of consideration, the things analyzed are the Judge's method of exploring, following, and understanding the case of the application for marriage dispensation after the enactment of Law Number 16 of 2019. Judges' considerations of Post-Law Number 16 the Year 2019 about marriage dispensation will be reviewed in terms of considerations by juridical and non-juridical. For

Juridical and Sociological Considerations of Judges in Granting Marriage Dispensation after Enactment Law No. 16 of 
example, considerations in law, Islamic law, the Applicant's social condition, actions, and usefulness. From the Judge's Creativity theory, the things analyzed are first, fluency in thinking, namely the ability to generate many ideas that come out of thinking quickly. In smooth thinking, what needs to be determined is quantity, not quality. Second, flexibility in thinking, namely the ability to produce several ideas for a variety of answers or questions, see a problem from different points of view and use various approaches or ways of thinking. Third, developing ideas and adding the details of an object, idea, and situation becomes more accessible and enjoyable. Fourth, think out an idea, as the ability to come up with unique ideas or spark original ideas so that they can find new laws. In terms of maqāsid asy-syā $r i^{\prime} a h$ theory, the things that the author analyzes are the level of need to be fulfilled or not at the request of the dispensation of Marriage, whether it includes daruriyyah, hajiyah, or tahsiniyah (Maimunah, 2018). Later the writer will analyze the potential maslahah and harm arising from the application and granting of marriage dispensation after Law Number 16 of 2019.

\section{RESULTS AND DISCUSSION}

\section{The Judges' Way to Assess Applications for Dispensation of Marriage}

\section{The completeness of documents in applying for a marriage dispensation}

The way the Judge assesses the marriage dispensation application submitted by the Applicant to the Religious Court is seen from the Completeness of the file.

This regulation is by the Supreme Court of the Republic of Indonesia Number 5 of 2019 concerning Guidelines for Adjudicating Applications for Marriage Dispensation in Article 5 (PERMA). "If the requirements as referred to in points 1 to 6 cannot be fulfilled, then other documents that explain the identity and educational status of the child and the identity of the parent/guardian can be used.

Following the authority of judges in Law Number 48 of 2009 concerning Judicial Power in article 5, paragraph 1, it explains that judges and judges of the constitution are obliged to explore, follow and understand legal values and a sense of justice that live in society. The obligation to explore, follow and understand the legal values of society is an absolute obligation for Judges in adjudicating cases. Based on the fact that every Judge's decision must be under the law and the community's sense of justice (Dewanto, 2020; Kurniawan, 2015).

In this case, the Judge has the authority to try cases and applications at the Religious Courts. As an institution mentioned in PERMA Number 5 of 2019, which is the authority to try marriage dispensation cases, this is very important to convey because it is related to the duties of judges at the Religious Courts. This PERMA contains new things related to how to try cases of the dispensation of Marriage after enacting this PERMA; this PERMA also applies to the General Court. Whereas the urgency of the socialization of PERMA Number 5 of 2019 concerning Guidelines

Juridical and Sociological Considerations of Judges in Granting Marriage Dispensation after Enactment Law No. 16 of 2019 


\section{Jurnal Ilmiah Al-Syir'ah Vol. 19, No. 2 (2021): 136-148 \\ Website: http://journal.iain-manado.ac.id/index.php/JIS ISSN 2528-0368 (online) ISSN 1693-4202 (print)}

for Adjudicating Applications for Marriage Dispensation for judges in the Religious Courts, because this PERMA continued from the birth of Law Number 16 of 2019 concerning Amendments to Law Number 1 of 1974 concerning Marriage which determine that Marriage is only permitted if a man and woman have reached the age of 19 (nineteen) years. This PERMA regulates new things and should serve as a guideline for all judges when hearing a marriage dispensation case.

Judges in granting the petition must consider it from a juridical and sociological perspective. In-Law Number 16 of 2019 about Marriage states that the age limit for Marriage is 19 (nineteen) years for both men and women. If you want to get married, but one of the prospective brides or both of them has not met the age limit, you are required to have a marriage dispensation letter from the local Religious Court. By Article 7 paragraph (2) which read:

(2) In the event of deviation from the age requirement as referred to in paragraph (1), the male and the parents of the female party can request dispensation to the Court on very urgent grounds accompanied by sufficient supporting evidence.

In connection with this Law that Indonesian citizens are obliged to obey the regulations set by the government, they must apply for dispensation of Marriage at the local religious Court, so that the purpose of the law is to provide dispensation of Marriage so that things prohibited by the law do not occur.

If the administrative requirements are complete, the files will be submitted to the Registrar for examination. Suppose the Clerk examines the application for marriage dispensation, it turns out that the administrative requirements are not fulfilled. In that case, the Registrar will return the application for dispensation of Marriage to the Applicant to be completed. The Applicant for dispensation of Marriage has met the administrative requirements; the application is registered in the register after paying the down payment of the court fee. In case the Applicant is unable to apply for dispensation of Marriage free of charge (prodeo). The requirements that must be met to process a prodeo application include 1) the Applicant's KTP, 2) a statement letter of incapacity which is made and signed by the Applicant and known to the head of the local Agarama Court, 3) a certificate of disability (SKTM) issued by the village or Sub-district, and 4) Certificate of other social benefits.

After receiving the administrative documents, the Judge reads and studies the application letter and the documents related to administration. Then after that, the Judge makes a Stipulation Day of Session (PHS) to carry out the trial. After that, the Judge will order the bailiff to summon the Applicant and order the Applicant to present his child requested for dispensation, the prospective husband/wife, parents/guardian of the prospective husband/wife, and bring two witnesses. 


\section{Jurnal Ilmiah Al-Syir'ah Vol. 19, No. 2 (2021): 136-148 \\ Website: http://journal.iain-manado.ac.id/index.php/JIS ISSN 2528-0368 (online) ISSN 1693-4202 (print)}

According to the author's opinion and based on the information from informants 1 and 2, the requirements put forward by the Applicant have met the requirements specified in the submission of a marriage dispensation application. With the fulfillment of these conditions, it can be registered after paying the downpayment of the court fee.

\section{The applicant's reason}

Suppose the problem of the research is related to the theory of authority. In this case, the Judge as one of the law enforcers who is given the authority to decide cases or determine applications regarding marriage dispensation for minors as stipulated in Law Number 16 of 2019, then the authority of the Judge in determining the application must be based on the principles of justice and the right to decide a case or determine that an application must be in accordance with applicable law.

The Judge who grants the petition must consider the juridical and sociological aspects; The Judge's consideration is one of the most important aspects to realize the value of a judge's decision that contains justice (ex aequo et bono). It contains legal certainty; besides, there are also benefits for interested parties so that the Judge's considerations must be considered carefully, correctly, and carefully (Arto, 2017).

When viewed from Law Number 16 of 2019 in Article 7 paragraph (1), which read:

Marriage is only permitted if the man and woman have reached the age of 19.

Juridically people who want to get married must be at least 19 years old. They get married below the predetermined age; it will have negative impacts, such as in education, health, and psychology. This regulation is strengthened by the Compilation of Islamic Law, which in this case in article 15 paragraph (2) which read 'for the benefit of the family and household, marriage can only be performed by the prospective bride who has reached the age specified in article 7 of Law Number 1, 1974.'

This provision allows for child marriage because, in Article 1 paragraph (1) of Law Number 23 of 2002 concerning Child Protection, it is stated that "a child is someone who is not yet 18 (eighteen) years old, including children who are still in the womb". For this reason, the government raises the age limit for Marriage so that people who want to get married are considered mature in spirit and able to get married to realize the goal of Marriage well without ending in divorce and getting married healthy and quality offspring.

Based on the authors' research results at the Palangkaraya Religious Court since the enactment of the revision of the new law, the rate of applications for marriage dispensation had increased compared to previous years before there was

Juridical and Sociological Considerations of Judges in Granting Marriage Dispensation after Enactment Law No. 16 of 2019 


\section{Jurnal Ilmiah Al-Syir'ah Vol. 19, No. 2 (2021): 136-148 \\ Website: http://journal.iain-manado.ac.id/index.php/JIS ISSN 2528-0368 (online) ISSN 1693-4202 (print)}

a change in the age limit for Marriage. Enactment of Law Number 16 of 2019 until now, 52 applications have submitted marriage dispensation to the Palangkaraya Religious Court, and all of these requests have been granted. This law shows the number of couples who want to get married at a young age.

Judging from the explanation above, the application for marriage dispensation at the Palangkaraya Religious Court is acceptable. The reason for avoiding intimacy and the second reason is that the Applicant has had sexual intercourse to cause pregnancy outside of Marriage. Based on these reasons, the Judge granted the marriage dispensation request for urgent reasons.

\section{Identification of applicants and witnesses}

The Judge assesses the application for marriage dispensation in the third stage, namely the identification stage of the Applicant and witnesses. In Article 12 of PERMA Number 5, judges in the trial must advise the Applicant, children, prospective husband/wife, and parents/guardians of the prospective husband/wife (Hamidi, 2020).

In the decision of the Palangkaraya Religious Court Number 35/Pdt.P/2020/PA.Plk that in the Supreme Court Regulation Number 5 of 2019 concerning guidelines for Adjudicating Marriage Dispensation Applications, he said that:

The Judge tried as much as possible to advise the Applicant about the risks of the Marriage that would be carried out and its impact on the child, namely: first, the possibility of cessation of education for the child, second, from the aspect of uterine health, adolescents tended not to be able to hold the prospective baby who should have been able to survive in the womb for at least nine months. If forced, it can cause premature labor, rupture of the membranes, miscarriage, susceptibility to infection, and pregnancy anemia. Third, psychological and mental readiness will have the potential for disputes and domestic violence if it is not mature. So the Judge advised the parties to postpone until the minimum age for Marriage.

During the examination at trial, the Judge identified:

1. The child who is submitted in the application knows and agrees to the marriage plan;

2. The psychological condition, health, and readiness of the child to marry and build a household life; and

3. Psychological, physical, sexual, or economic coercion on the child and family to marry or marry the child.

In addition, in examining the Judge taking into account the best interests of the child, the Judge in the examination shall do the following (Hamidi, 2020):

Juridical and Sociological Considerations of Judges in Granting Marriage Dispensation after Enactment Law No. 16 of 


\section{Jurnal Ilmiah Al-Syir'ah Vol. 19, No. 2 (2021): 136-148 \\ Website: http://journal.iain-manado.ac.id/index.php/JIS ISSN 2528-0368 (online) ISSN 1693-4202 (print)}

1. Studying carefully and carefully the Petitioner's petition;

2. Checking the Petitioner's legal standing;

3. Exploring the background and reasons for child marriage;

4. Digging up information related to whether there are marital obstacles or not;

5. Digging up information related to the child's understanding and consent to be married;

6. Taking into account the age difference between the child and the prospective husband/wife;

7. Hearing the statement of the Applicant, children, prospective husband/wife, and parents/guardians of the prospective husband/wife;

8. Paying attention to the psychological, sociological, cultural, educational, health, economic conditions of children and parents, based on recommendations from psychologists, doctors/midwives, professional social workers, social welfare workers, the integrated service center for the protection of women and children (P2TP2A) or the Protection Commission Indonesian / Regional Children (KPAI/ KPAD);

9. Paying attention to the presence or absence of elements of psychological, physical, sexual, and economic coercion; and

10. Ensuring parental commitment to take responsibility for children's economic, social, health, and educational issues.

Then the Judge also asked the Applicant's child and the Applicant's future wife/husband of the Applicant's related identity, age, desire to marry, and other necessary things. The Applicant's children and the Judge have examined the validity of the documents submitted by the Applicant. Suppose the Applicant's reason for applying for dispensation is due to pregnancy. In that case, she should attach a certificate from the doctor and a letter of rejection from the KUA.

The reasons for the decision making by the Judge in granting dispensation of Marriage are the first, whether it is by the applicable regulations. The Marriage to be carried out must meet the requirements contained in the statutory regulations. As stipulated in Marriage Law Number 16 of 2019, it has stipulated the basis and conditions that must be met in Marriage. One of them is the provision in Article 7 paragraph (1) regarding the age limit for Marriage.

Second, there is no prohibition on Marriage. Every Marriage that takes place must not be prohibited from Marriage either according to religion or statutory regulations. Third: Maturity in terms of maturity and financial (Hs, 2011). Fourth: Both parents agree, and in an urgent situation, the Judge will grant it if those who are not old enough are really in an urgent situation. It is like husband and wife who cause pregnancy out of wedlock, related to religious norms. Parents who know the relationship of their children to the opposite sex will certainly constantly monitor their behavior. How do children today behave when dating makes parents worry if they do an outrageous thing and commit adultery. Based on rejecting or avoiding the greater mafsadat, parents want their children to get married. So to avoid things

Juridical and Sociological Considerations of Judges in Granting Marriage Dispensation after Enactment Law No. 16 of 2019 
that are not desirable and which ones are more useful or vice versa, the Judge can grant the request for dispensation of Marriage (Setiasih, 2017).

The Judge's Consideration in Granting Marriage Dispensation after the Enactment of Law Number 16 of 2019 at The Palangkaraya Religious Court

\section{Abstaining from adultery}

Based on the results of the author's interviews with the five subjects at the Palangkaraya Religious Court, one of them was the ZH subject; he said that:

The reasons are too classic, usually because they have been dating for a long time, have been too close to be together often, and are worried that unwanted things will happen and also because they are pregnant.

Of course, every Judge who wishes to grant a marriage dispensation application must be based on specific reasons, and the grant is for the benefit of the parties to be married. In the case of granting permission for Marriage Dispensation at the Religious Court, the Judge previously advised the party applying for marriage dispensation because the Religious Court does not automatically accept all requests supported by fundamental reasons that can strengthen the petition.

As said by the five subjects: The Judge granted the request for dispensation of Marriage because he saw the condition of the child's association which was too free, often met with his girlfriend and was often together as a husband and wife, even though they were not married. Therefore, it is feared that unwanted things will happen and maintain the family's good name, so the parents want to marry the child even though the child is not yet 19 years old.

Judges also need to consider juridical and sociological aspects, in addition to the age limit for minors and proof of requirements in the form of application letters, ID cards of both parties, KK (family cards), rejection letters from the Office of Religious Affairs (KUA) and so on. The Judge also ascertained whether the child being married was not a relationship that prevented the Marriage, either because of blood or not in someone else's Marriage.

Suppose the prospective husband or wife is deemed ready to be given household responsibilities even though their age is insufficient. This reason sees the benefit as a reason for accepting applications for marriage dispensation. With these considerations, it can protect one of the five objectives of Islamic law, namely hifz ad din (maintaining religion). And also, if the prospective husband/wife has a strong desire to marry, it is also because the two of them are closely related so that there is a concern that adultery will occur. Here the Judge views benefit as a reason for acceptance of the application for marriage dispensation because it is related to hifz ad din (maintaining religion). This condition is also because the provision of the dispensation of Marriage for children is an effort to realize hifz an nasl (keeping

Juridical and Sociological Considerations of Judges in Granting Marriage Dispensation after Enactment Law No. 16 of 


\section{Jurnal Ilmiah Al-Syir'ah Vol. 19, No. 2 (2021): 136-148 \\ Website: http://journal.iain-manado.ac.id/index.php/JIS ISSN 2528-0368 (online) ISSN 1693-4202 (print)}

offspring); this effort is seen as a way to prevent children from committing adultery (Al-Qardhawi, 2006).

Related to hyifz\} al 'aql (maintaining reason) because Marriage is carried out at a relatively young age, it is feared that it will cause a fight between husband and wife whose emotions are unstable because they are still immature. At least maturity can be a controller in behaving and acting, so there will not always be arguments and selfishness in married life.

According to the author, what is decided by the Judge is appropriate if it is based on maqāsid asy syäri 'ah and the rules of fiqh dar'ul mafásid muqaddamun 'ala jalbil mașälih. It is because after being studied, if the action is allowed to cause mudāarat which is more significant than marrying them off. However, Marriage should be avoided as much as possible because the age below 19 years is a young age to build a household, especially emotional maturity is not yet ripe. Underage marriages often end in divorce because running a household is not always sweet but also bitter. Therefore, if married underage, it would be better to consider it because emotionally immature, it is feared that they will make quick decisions without considering the consequences. In this case, one can choose which one is more beneficial or, on the contrary, causes harm to the Applicant.

Teenagers are when they know the outside world, friends that have never been met, including the opposite sex. Sexual drive in the form of attraction to the opposite sex is expected and normal. However, it is different when a child or adolescent starts to recognize dating. In this case, of course, the parents will worry and try to prohibit it. However, parents cannot control a child outside the home because they are often busy with work, so control over children cannot be exercised. As happened in several cases of marriage dispensation at the Palangkaraya Religious Court, a teenager has been dating for 1 to 2 years, and their relationship is very close like a husband and wife. Parents are worried that something is unwanted or violates religious law. Then the two sides of the family deliberated to get married but were constrained by the age that was still under age stipulated in the Marriage Law; because the KUA employee rejected it, they had to apply for a marriage dispensation first at the local Religious Court.

\section{Unwed pregnancy}

The reason for the marriage dispensation request submitted by the Applicant to the Religious Court is because of promiscuity in which they have intercourse with two minors. One of the reasons is because the prospective woman is pregnant or pregnant.

In this case, the Judge has the basis and factors used in granting a dispensation to underage Marriage as the consideration of benefit. If the prospective bride and groom do not marry immediately, concerns will violate religious norms and prevailing regulations.

Juridical and Sociological Considerations of Judges in Granting Marriage Dispensation after Enactment Law No. 16 of 2019 


\section{Jurnal Ilmiah Al-Syir'ah Vol. 19, No. 2 (2021): 136-148 \\ Website: http://journal.iain-manado.ac.id/index.php/JIS ISSN 2528-0368 (online) ISSN 1693-4202 (print)}

The reason for the marriage dispensation request submitted by the Applicant to the Religious Court is because of promiscuity in which they have intercourse with two minors. One of the reasons is because the prospective woman is pregnant.

In this case, the Judge has the basis and factors used in granting a dispensation to underage Marriage, namely the consideration of benefit. If the prospective bride and groom do not marry immediately, concerns will violate religious norms and prevailing regulations.

The authors conclude that underage Marriage on the grounds of being pregnant outside of wedlock may be carried out provided that he is married to the man who impregnated him because there is a law that becomes the legality of deviation from the age limit for Marriage. However, we need to know that the Marriage of minors hurts the normal development of children. It is recommended that parents pay more attention to their children to avoid promiscuity, which eventually leads to pregnancy outside of Marriage.

\section{CONCLUSION}

The Judge assesses the application for Marriage Dispensation is seen from the Completeness of the documents determined to register so that the application can be accepted. The reasons submitted are very urgent. In this case, the Judge granted the marriage dispensation request because the Applicant was considered a legal subject. However, judges at the Palangkaraya Religious Court need to be prosecuted for their creativity in deciding an accepted case. Judges have the freedom to decide a case and consider the benefits and harm obtained in the future.

The reason the Judge granted the request for dispensation of Marriage was seen from the reasons put forward by the Applicant, namely avoiding adultery and getting pregnant outside of Marriage. The Judge found that the Marriage was urgent because they were engaged, and their relationship was so close. So it is feared that acts prohibited by religion will occur if they are not married off immediately. The Judge also considered no obstacle to Marriage between the Petitioners' children and their prospective husband/wife because they were not related by blood and onesided siblings. It is jalbil masălih because after being studied, more harm can be obtained by leaving them without marital ties.

\section{ACKNOWLEDGMENTS}

The authors thank the Rector IAIN Palangkaraya for his support and direction. Therefore, this article can be completed and published. Then, we also appreciate the Dean of Sharia Faculty at IAIN Palangkaraya and also thanks to judges of Palangkaraya religious court, all staff, and parties involved in completing this article.

Juridical and Sociological Considerations of Judges in Granting Marriage Dispensation after Enactment Law No. 16 of 


\section{Jurnal Ilmiah Al-Syir'ah Vol. 19, No. 2 (2021): 136-148 \\ Website: http://journal.iain-manado.ac.id/index.php/JIS ISSN 2528-0368 (online) ISSN 1693-4202 (print)}

\section{REFERENCES}

Adhim, M. F. (2006). Indahnya Pernikahan DIni. Gema Insani.

Ali, Z. (2007). Hukum Perdata Islam di Indonesia. Sinar Grafika.

Ali, Z. (2015). Metode Penelitian Hukum. Sinar Grafika.

Al-Qardhawi, Y. (2006). Fiqih Maqasid Syariah. Pustaka alKautsar.

Arto, M. (2017). Praktek Perkara Perdata Pada pengadilan Agama. Pustaka Pelajar.

Dewanto, P. (2020). Rekonstruksi Pertimbangan Hakim terhadap Putusan Sengketa Perdata Berbasis Nilai Keadilan. Jurnal Ius Constituendum, 5(2), 303-324.

Hamidi. (2020). Dispensasi Kawin Menurut Perma Nomor 5 Tahun 2019. Artikel.

Hs, I. A. (2011). Dispensasi Perkawinan Perspektif Perlindungan Anak. Ilmiah Ilmu Hukum QISTI, 5.

Kurniawan, R. (2015). Penemuan Hukum oleh Hakim dalam Perkara Pidana Berdasarkan Undang-undang Nomor 48 Tahun 2009 Tentang Kekuasaan Kehakiman. Riau University.

Maimunah, M. (2018). Politik Islam Perspektif Maqashid Syariah. El Mashlahah, 1. https://doi.org/https://doi.org/10.23971/el-mas.v8i1.1093

Setiasih, W. (2017). Analisis Putusan Dispensasi Nikah Dibawah Umur Dalam Perspektif Perlindungan Perempuan. PPKM III, III, 235-245.

Slamet, A., \& Aminudin. (1999). Fiqih Munakahat 1. Pustaka Setia.

Supiana, M. (2003). Materi Pendidikan Agama Islam. Remaja Rosdakarya.

Utsman, S. (2008). Dasar-Dasar Sosiologi Hukum. Pustaka Pelajar.

Utsman, S. (2014). Metode Penelitian Hukum Progresif. Pustaka Pelajar. 